\title{
Formalin Contaminated in Seafood and Frozen Meat at Somdet Market, Kalasin Province
}

\author{
Theeranat Suwanaruang \\ Faculty of Science and Health Technology, Kalasin University, Kalasin, Thailand \\ Email: drtheeranat@gmail.com
}

How to cite this paper: Suwanaruang, T. (2018) Formalin Contaminated in Seafood and Frozen Meat at Somdet Market, Kalasin Province. Journal of Environmental Protection, 9, 1286-1293.

https://doi.org/10.4236/jep.2018.912080

Received: September 11, 2018

Accepted: November 16, 2018

Published: November 19, 2018

Copyright $\odot 2018$ by author and Scientific Research Publishing Inc. This work is licensed under the Creative Commons Attribution International License (CC BY 4.0).

http://creativecommons.org/licenses/by/4.0/

\begin{abstract}
Formaldehyde or formalin is highly toxic that is absorbed pleasantly by inhalation. The object of this research was to analyze formalin that contaminated in seafood and frozen meat. The method was to select samples at Kalasin Province. The samples were mackerel, crisp squid, frozen chicken, Saba fish, Shishamo fish, Jelly fish, Cockle, Clams, Squid, shrimp, White shrimp and Dolly fish, respectively. The methods were to analyze formaldehyde with titration and formalin test kit. Titration method used formic acid by excess of iodine in alkaline solution. Formalin test kit of Ministry of Public Health issued Act No.151 (B.E.2536) was to test formalin contaminated food. The results found formaldehyde in mackerel, crisp squid, frozen chicken, Saba fish, Shishamo fish, jelly fish, cockle, clams, squid, shrimp, white shrimp and dolly fish in three replicated were $288 \mathrm{mg} / \mathrm{L}, 228 \mathrm{mg} / \mathrm{L}, 293 \mathrm{mg} / \mathrm{L}, 77 \mathrm{mg} / \mathrm{L}, 282$ $\mathrm{mg} / \mathrm{L}, 180 \mathrm{mg} / \mathrm{L}, 120 \mathrm{mg} / \mathrm{L}, 48 \mathrm{mg} / \mathrm{L}, 229 \mathrm{mg} / \mathrm{L}, 294 \mathrm{mg} / \mathrm{L}, 295 \mathrm{mg} / \mathrm{L}$ and 293 $\mathrm{mg} / \mathrm{L}$, respectively. Formalin test kit was to found all samples were contaminated with formalin. Moreover, the height formalin contaminated in white shrimp, the second were shrimp and dolly fish, the third was frozen chicken, the fourth was mackerel, the fifth was Shishamo fish, the sixth was squid, the seventh was crisp squid, the eighth was jelly fish, the ninth was cockle, the tenth was Saba fish and the last was clam. The World Health Organization classified formaldehyde was carcinogenic to humans, considerately that there was a decent proof for inflicting cavity cancer in humans.
\end{abstract}

\section{Keywords}

Formalin, Seafood, Frozen Meat, Carcinogenic

\section{Introduction}

Formaldehyde exists in several animal and plant species as a product of their traditional metabolism. Formaldehyde is unlikely to cause acute results; however 
body process of an outsized quantity of aldehyde will typically cause severe abdominal pain, vomiting, coma, nephritic injury and potential death. However, Health Organization (WHO), the general population is exposed to formaldehyde in the main by inhalation. The main health concern of aldehyde is its cancer inflicting ability. The International Agency for analysis on cancer of the World Health Organization classified formaldehyde as carcinogenic to humans, considerately that there was a decent proof for inflicting cavity cancer in humans. The WHO, on the opposite hand, thought of that the proof indicated that aldehyde was not malignant neoplastic disease upon body process. The amount of aldehyde will accumulate in sure marine fish throughout frozen storage and Crustacea once death. Its levels were rumored to be up to four hundred $\mathrm{mg} / \mathrm{kg}$ in Bombay-duck once cold storage. The detection of dimethylamine in Bombay-duck was accustomed distinguish whether or not aldehyde had been further deliberately. aldehyde is that the simplest member of organic compound family however a awfully reactive chemical, wherever the aerosolized type is understood as aldehyde and also the liquid type as a solution. Characteristically, aldehyde could be a colorless, strong-smelling, irritating, poisonous, and ignitable gas and its statement is $\mathrm{CH}_{2} \mathrm{O}$ that is additionally referred to as aldehyde, ordinarily made by the chemical reaction of alcohol.

Formaldehyde is a chemical unremarkably utilized in trade for the producing of plastic resins which will be utilized in wood, paper and textile trade. Formalin, that could be a resolution of regarding thirty seventh gas, is disinfectant and preservative for unit merchandise. Gas is omnipresent within the surroundings, because it is made from each natural and manmade source. It exists at low levels in most living organisms as a metabolic intermediate. Major manmade supply of gas includes combustions (e.g., engine exhaust, wood burning). Formaldehyde is cancer to human, it's necessary to analyze the content of gas in fish and food since they're claimed to be the main supply and so providing additional data to the assembly of safe and hygienical food [1]. Therefore, keeping fish contemporary in ice for quite one week is tough and additionally depends upon the species chosen. The problem becomes additional necessary to a rustic like Nepal wherever the fish provide at intervals the country doesn't meet the domestic would like and it should be foreign from different countries, mainly India. Lately, several reports publicly media have targeted to the matter of wholesalers and vendors treating fish with gas resolution (formalin) to preserve period so as to cut back their price and increase revenues at the value of public health [2]. Formaldehyde could be a member of organic compound family that happens within the vaporous type whereas the liquid type is formol created of thirty seventh gas by weight. Gas is wide utilized in chemical industries and additionally as a disinfectant and preservative. Significantly, International Agency for analysis on Cancer (IARC) has classified gas as a gaggle I substance to humans [3]. Formaldehyde has been determined at completely different concentrations in several food things reminiscent of fruits, vegetables, meat, fish etc. The forms as a result of traditional metabolism in plants and animals. additionally, there's a mechanism 
of formation of formaldehyde throughout the ageing and deterioration of fish flesh. However, the ensuing aldehyde conjointly converts to different chemical compounds; so high levels of aldehyde don't accumulate within the fish tissue [4]. Formaldehyde used preponderantly within the synthesis of resins, with urea-formaldehyde resins and different organic compound [5] urban center Government conjointly suggested to the general public to settle on solely fish that area unit recent and avoid those with uncommon smell; and avoid shopping for fish that area unit stiff (formaldehyde might stiffen flesh of fish). Besides, public conjointly suggested to clean and cook food merchandise completely as aldehyde is water soluble and will dissipate upon heating. The aldehyde concentration was bated when cooking and boiling [6]. Twenty Human studies have shown that chronic inhalation exposure to aldehyde is related to metabolism symptoms and eye, nose and throat irritation [7]. On the opposite hand, the oral exposure to aldehyde relating to the induction of channel lesion. There are cases of general or localized aversion attributed to the aldehyde are rumored in vesture and textiles bank note paper, medical treatment and home and private care [8].

The purpose of this research was to analyzed formalin that contaminated in seafood and frozen meat samples in Somdet market Kalasin Province.

\section{Materials and Methods}

\subsection{Selected Samples}

The method was to selected samples in Somdet market Kalasin Province. The samples were mackerel, crisp squid, frozen chicken, Saba fish, Shishamo fish, Jelly fish, Cockle, Clams, Squid, shrimp, White shrimp and Dolly fish.

\subsection{Titration Method}

The method was modified from [9], this technique with volumetric analysis that was to change quantitatively to acid by iodine in alkalescent resolution. Formaldehyde is also calculable in resolution by oxidizing it to acid by suggests that of a legendary amount (in excess) of iodine dissolved in associate far more than $\mathrm{NaOH}$ resolution (hypoiodite solution).

1) The acid therefore shaped is neutralized by the alkali gift. The unreacted hypoiodite is then acidified with HCI and therefore the liberated iodine is titrated with commonplace fixer resolution victimization starch as indicator. Formalin solution: Weigh out accurately regarding one. $0 \mathrm{~g}$ of formal resolution, transfer it during a $250 \mathrm{~cm}^{3}$ meter flask and compose to the mark with water.

2) Volumetric analysis with Iodine resolution (Blank titration): measuring device out fifty $\mathrm{cm}^{3}$ of iodine resolution during a $250 \mathrm{~cm}^{3}$ cone-shaped flask. Quantify this resolution with commonplace fixer resolution. Fixer resolution is standardized by titrating against dichoromate resolution. The procedurals details for the strandardisation are given in Experiment 9b. Repeat the volumetric analysis to urge at least 2 concordant readings. Record the observation in Observa- 
tion Table 1.

3) Volumetric analysis with formole Solution: measuring device out $25 \mathrm{~cm}^{3}$ of samples formalin resolution during a $250 \mathrm{~cm}^{3}$ cone-shaped flask and add fifty $\mathrm{cm}^{3}$ of zero. $1 \mathrm{M}$ iodine resolution. Resolution develops a chromatic color. Currently add $2 \mathrm{M} \mathrm{NaOH}$ resolution from the measuring system into the cone-shaped flask till the answer becomes straw in color. Shake the contents of the flask and permit to face for quarter-hour. Acidify with forty $\mathrm{cm}^{3}$ of $2 \mathrm{M}$ acid to liberate the remaining iodine. Quantify this resolution with fixer resolution $(0.1 \mathrm{M})$ victimization starch as indicator.

\subsection{Test Kit for Formalin in Food}

Test Kit for Formalin in Foodof Ministry of Public Health issued Act No.151 (B.E.2536) was to specify the use of formalin in food is prohibited.

Sensitivity of Test Kit Detectionlimit: $0.5 \mathrm{mg} / \mathrm{kg}$ [10].

\section{Results}

The results with titration method found formaldehyde contaminated in mackerel, crisp squid, frozen chicken, Saba fish, Shishamo fish, Jelly fish, Cockle, Clams, Squid, shrimp, White shrimp and Dolly fish in three replicated were 288 $\mathrm{mg} / \mathrm{L}, 228 \mathrm{mg} / \mathrm{L}, 293 \mathrm{mg} / \mathrm{L}, 77 \mathrm{mg} / \mathrm{L}, 282 \mathrm{mg} / \mathrm{L}, 180 \mathrm{mg} / \mathrm{L}, 120 \mathrm{mg} / \mathrm{L}, 48 \mathrm{mg} / \mathrm{L}$, $229 \mathrm{mg} / \mathrm{L} 294 \mathrm{mg} / \mathrm{L}, 295 \mathrm{mg} / \mathrm{L}$ and $293 \mathrm{mg} / \mathrm{L}$, respectively.

Formalin test kit was to found samples in Somdet market were contaminated with formalin in every sample.

Table 1. Iodine solution and sodium Thiosulphate solution.

\begin{tabular}{cccc}
\hline Samples & Volume of Iodine & Volume of Sodium thiosulfate & Formalin $^{\star}(\mathrm{mg} / \mathrm{L})$ \\
\hline Mackerel & 50 & 2 & 288 \\
Crisp Squid & 50 & 12 & 228 \\
Chicken & 50 & 1.2 & 292.8 \\
Saba & 50 & 37.1 & 77.4 \\
Shishamo & 50 & 3 & 282 \\
jellyfish & 50 & 20 & 180 \\
Cockle & 50 & 30 & 120 \\
Clams & 50 & 42 & 48 \\
Squid & 50 & 11.8 & 229.2 \\
Shrimp & 50 & 1 & 294 \\
Whiteleg shrimp & 50 & 0.9 & 294.6 \\
Dolly fish & 50 & 1.1 & 293.4 \\
\hline
\end{tabular}

${ }^{*}$ Formalin $=(50-$ Volume of Sodium thiosulfate $\left.){ }^{\star} 0.00015 * 100 / 25\right) \times 10,000$ 


\section{Conclusion}

The height formalin contaminated in white shrimp, the second were shrimp and dolly fish, the third was frozen chicken, the fourth was mackerel, the fifth was Shishamo fish, the sixth was squid, the seventh was Crisp Squid, the eighth was jelly fish, the ninth was cockle, the tenth was Saba fish and the last was clam.

\section{Discussion}

Consumer advice to deplete the dosage of formalin. Washing all food totally with running water, as formaldehyde is soluble in water and laundry will aid the removal of formaldehyde. Soak dry groceries like dried mushrooms totally in clean water before change of state and discard the water. Cook all food totally to an indoor high temperature or higher than, as heat from change of state may also aid the removal of aldehyde. For fish, check the flesh to visualize whether or not it's turned opaque and may be separated simply. supply food merchandise from credible sources. Do not add formaldehyde to food, during this situation, several fish traders use formal to forestall spoilage and increase period of time Fish is a vital food stuff and supply everywhere [11]. The fishes traders whereas transporting to domestic promoting chain to forestall spoilage and increase period of time [12].

In 2011, the National pharmacological medicine program, associate interagency program of the department of health and human services, named aldehyde as a known human substance in its twelfth Report on Carcinogens. The harmful and potential supply of peril to human some fish traders engaged in treating fish with formaldehyde. Moreover, formaldehyde in food and food resulting in the numerous analyses associated aldehyde determination so as to live and management aldehyde quantity in food [13]. The several studies showed that aldehyde exposure will cause eczema, eye irritation, respiration irritation, respiratory disorder and respiratory organ swelling. Some studies have found that formaldehyde will cause metabolism cancer and can also increase the speed of malignant neoplastic disease. moreover, many ways are urged to cut back aldehyde in food equivalent to change of state and laundry. The finding of the many health impact of aldehyde, suggests that the investigation of level of aldehyde in food ought to be done and additionally the extent of aldehyde natural production [6]. Even those that spray or inject over a protracted amount of your time can seemingly suffer health complications equivalent to cecity, respiratory disorder and even carcinoma [14] Environmental Protection Agency (EPA), most daily dose reference (RfD) aldehyde is zero. $2 \mu \mathrm{g} / \mathrm{g}$ body weight per day [1]. The result foreign fishes from neighboring countries enter within the domestic market and it absolutely was reported that over eighty weight unit of fish and work merchandise enter into People's Republic of Bangladesh daily through the border from Myanmar [15] Sea foods square measure a budget supply of animal that come back once meat and poultry animal foods. Food is a crucial diet for several individuals because of their distinctive organic process composition. Be- 
cause the world population is growing, the per capita consumption of food is additionally increasing speedily. The low-fat content of the many ocean foods and therefore the result on coronary cardiopathy of the $n-3$ unsaturated fatty acids in fatty oceanic fish species square measure very important facet for health acutely aware individuals notably in affluent countries wherever disorder mortality is high [16]. Immaculate, J. and Jamila, P. 2018 found that top methanol content in un-iced fishes. However, methanol content of all the iced soldier species was still under five $\mathrm{mg} / \mathrm{kg}$ wherever because the un-iced fishes had higher content. However, there have been some limitations during this study similar to the action, time of storage and handling might presumably influence the concentrations of methanol since it's a volatile compound. The adverse health effects on human because of the $(<5 \mathrm{mg} / \mathrm{kg})$ formalin contaminated fish consumption supported the chance assessment calculation [17]. The study proves fishes from landing center are often thought of safe for consumption as a result of recent condition. Additional a lot of forthwith correct icing will probably cut back the formation of methanol. Formaldehyde is of course made associated developed by acatalyst reduction throughout postmortem of marine fish and crustaceans. The catalyst reduction results in the breakdown of trimethylamine compound and dimethylamine [18]. The metabolized naturally in our bodies by traditional metabolism and may even be found within the air, natural food, some skin-care merchandise further as preservatives in processed food, particularly in dried and food product. Formaldehyde was produced by enzymatic decomposition of trimethylamine-oxide (TMAO) to equimolar amounts of formaldehyde (FA) and dimethylamine (DMA) in seafood during postmortem storage and the general reaction equation is TMAO $\rightarrow$ DMA + formaldehyde [19]. Other than that, is perishable and it are often destroyed through the chemistry processes that occur within the atmosphere, by biological actions within the body and natural processes in soil and water. It conjointly classified because the simplest organic compound and its systematic name is fuel [20]. The fish keep for a protracted amount in close temperature in un-iced condition is that the reason for the increase in the hydrogen ion concentration values that results in higher quantity of volatile amines with production [21]. Wherever the formation of trimethylamine and square measure answerable for the suspicious odor [13].

\section{Conflicts of Interest}

The authors declare no conflicts of interest regarding the publication of this paper.

\section{References}

[1] Noordiana, N., Fatimah, A.B. and Farhana, Y.C.B. (2011) Formaldehyde Content and Quality Characteristics of Selected Fish and Seafood from Wet Markets. International Food Research Journal, 18, 125-136.

[2] Joshi, R., Bhatta, R., Paudel, P.N. and Kafle, B.K. (2015) Formaldehyde Content of Selected Fish from the Wet Markets of Kathmandu Valley. International Food Re- 
search Journal, 22, 1434-1437.

[3] IARC (2004) Monographs on the Evaluation of Carcinogenic Risks to Humans, Vol. 88, Formaldehyde, 2-Butoxyethanol and 1-Tert-Butoxy-2-Propanol. International Agency for Research on Cancer, Lyon.

[4] Bianchi, F., Careri, M., Musci, M. and Mangia, A. (2007) Fish and Food Safety: Determination of Formaldehyde in 12 Fish Species by SPME Extraction and GC-MS Analysis. Food Chemistry, 100, 1049-1053. https://doi.org/10.1016/j.foodchem.2005.09.089

[5] Prado, O.J., Veiga, M.C. and Kennes, C. (2007) Removal of Formaldehyde, Methanol, Dimethylether and Carbon Monoxide from Waste Gases of Synthetic Resin-Producing Industries. Chemosphere, 70, 1357-1365.

https://doi.org/10.1016/j.chemosphere.2007.09.039

[6] Norliana, S., Abdulamir, A.S., Abu Bakar, F. and Salleh, A.B. (2009) The Health Risk of Formaldehyde to Human Beings. American Journal of Pharmacology and Toxicology, 4, 98-106.

[7] Naya, M. and Nakahashi, J. (2005) Risk Assessment of Formaldehyde for the General Population in Japan. Regulatory Toxicology and Pharmacology, 43, 232-248. https://doi.org/10.1016/j.yrtph.2005.08.002

[8] Donovan, J. and Skotnicki-Grant, S. (2007) Allergic Contact Dermatitis from Formaldehyde Textile Resins in Surgical Uniforms and Nonwoven Textile Masks. Dermatitis, 18, 40-44. https://doi.org/10.2310/6620.2007.05003

[9] Fernandez, J.P.S., Mendoza, M.D.V., Torre, B.C.B. and De Castro Quinto, E. (2016) Development of a Detection Method of Formalin in Foods Based on Chromotropic acid Test. Regional Symposium of Chemical Engineering, At Petro Hotel Vung Tau City.

[10] Medical Sciences Innovation for Healthy Thailand (2018) Medical Sciences Innovation for Healthy Thailand. Thailand 4.0 Conference, Bangkok, 26-31 March 2018, 144.

[11] Uddin, R., Wahid, M., Jesmeen, T., Huda, N.H. and Sutradhar, K.B. (2011) Detection of Formalin in Fish Samples Collected from Dhaka City, Bangladesh. Stamford Journal of Pharmaceutical Sciences, 4, 49-52.

[12] Yeasmin, T., Reza, M.S., Khan, M.N.A., Shikha, F.H. and Kamal, M. (2010) Present Status of Marketing of Formalin Treated Fishes in Domestic Markets at Mymensingh District in Bangladesh. International Journal of Biological Research, 1, 21-24.

[13] Cui, X., Fang, G., Jiang, L. and Wang, W. (2007) Kinetic Spectrophotometric Method for Rapid Determination of Trace Formaldehyde in Foods. Analytica Chimica Acta, 590, 253-259. https://doi.org/10.1016/j.aca.2007.03.042

[14] Hossain, M.S., Rahman, M.A., Sharkar, T.K. and Shahjalal, H.M. (2008) Formaldehyde Content in the Rui Fish (Labeorohita) in Bangladesh and Effect of Formaldehyde on Lipid Peroxidation in Rat Liver and Intestinal Tissues. International Journal of Medical Sciences, 8, 405-409. https://doi.org/10.3923/jms.2008.405.409

[15] Jung (2004) Formaldehyde Residues in Formalin Treated Olive Flounder (Paralichthys olivaceus), Black Rockfish (Sebastes schlegeli) and Seawater Aquaculture. Journal Source Aquaculture, 194, 251-262.

[16] Adebayo, T.A.C., Odu, N.N., Michael, M.U. and Okonko, I.O. (2012) Multi-Drug Resistant (MDR) Organisms Isolated from Sea-Foods in Uyo, South-Southern Region of Nigeria. Nature and Science, 10, 61-70.

[17] Immaculate, J. and Jamila, P. (2018) Quality Characteristics Including Formalde- 
hyde Content in Selected Sea Foods of Tuticorin, Southeast Coast of India. International Food Research Journal, 25, 293-302.

[18] Badii, F. and Howell, N.K. (2002) Changes in the Texture and Structure of Cod and Haddock Fillets during Frozen Storage. Food Hydrocolloids, 16, 313-319. https://doi.org/10.1016/S0268-005X(01)00104-7

[19] Kimura, M., Seki, N. and Kimura, I. (2003) Thermodynamic Compensation of Urea and Trimethylamine N-Oxide Interactions with Protein. Biophysical Journal, 85, 108-125.

[20] Zhang, L., Steinmaus, C., Eastmond, D.A., Xin, X.K. and Smith, M.T. (2008) Formaldehyde Exposure and Leukemia: A New Meta-Analysis and Potential Mechanisms. Mutation Research, 681, 150-168. https://doi.org/10.1016/j.mrrev.2008.07.002

[21] Kyrana, R., Vasiliki, P. and Lougovois, V. (2002) Sensory, Chemical and Microbiological Assessment of Farmraised European Sea Bass (Dicentrarchus labrax) Stored in Melting Ice. International Journal of Food Science and Technology, 37, 319-328. https://doi.org/10.1046/j.1365-2621.2002.00572.x 